\title{
CIPP Model Evaluation of the 2013 Curriculum Implementation Training Program in Jakarta - Indonesia (Case Study: Islamic Educational Supervisor)
}

\author{
Zulfakhri Sofyan $^{1}$, Bedjo Sujanto ${ }^{1} \&$ Muchlis R. Luddin ${ }^{2}$ \\ 1 Management Pendidikan, Universitas Negeri Jakarta, Indonesia \\ ${ }^{2}$ Sosiologi, Universitas Indonesia, Indonesia \\ Correspondence: Zulfakhri Sofyan, Managemen Pendidikan, Universitas Negeri Jakarta, Rawamangun, Pulo \\ Gadung, Jakarta Timur, DKI Jakarta, Indonesia. E-mail: zulfakhri.sofyan@gmail.com
}

Received: August 20, 2019

doi:10.5539/ass.v15n12p20
Accepted: October 1, 2019 Online Published: November 13, 2019

URL: https://doi.org/10.5539/ass.v15n12p20

\begin{abstract}
The purpose of this study was to evaluate the Implementation of the 2013 curriculum training program for Islamic Educational Supervisors and to measure their capacity in terms of 2013 curriculum competency using the CIPP model of evaluation.

The importance of improving the competency of Educational Supervisor through Implementation training program of 2013 curricula, because they hold a very significant and strategic role in improving the quality teaching of Islamic Educational teachers (Guru PAI), acted as educational supervisor, counselor, and motivator.

This article would like to answer several questions; how the Implementation of Curriculum 2013 training was able to boost the Islamic Educational Supervisor Competency in terms of their academic ability. The paper aims to discuss the issue of Islamic Supervisor in terms of curriculum 2013 competency.
\end{abstract}

Keywords: CIPP Model of Evaluation, 2013 curriculum implementation program, Strategic Role of Islamic Educational Supervisor, Islamic Educational supervisor competency, Islamic Studies Regulation

\section{Introduction}

By the introduction to a new 2013 curriculum, the Indonesian Government, through ministry of National education hopes that the quality of education in Indonesian in the future will be better, respectable and we do expect that, this a new 2013 curriculum is able to improve the quality of Indonesian educational system with a number of solutions to various national educational problems by preparing our students through a better curriculum planning, curriculum implementing, and curriculum evaluating as a part of teaching and learning process, so the learning process can take place efficiently and effectively. This 2013 curriculum was intended to create a better young generation that is ready for their future. Changing the learning paradigm is the most important part of the policy of the implementation of a new 2013 curriculum.

This a new curriculum is designed to reconfigure the learning process and student/teacher relationships that have traditionally been taking place, where the teacher plays a role as an active agent (all-knowing person) and students are passive, only accepting, memorizing and repeating information. This circumstance must change, where a classroom is a place for sharing experiences and gaining new knowledge from students and teachers generated through dialogue and shared experiences.

The 2013 curriculum was designed not only to create a balance in the learning process but also to change the way students learn to be more active and to become the center/center of learning and the teacher only as a companion.

Under the regulation and policies set by the Ministry of Education, stated that; the 2013 curriculum is projected for three main elements of Education management bodies of school, such as Teachers, Principals, and Educational Supervisor. In order for establishing a quality Islamic Educational Supervisor, various efforts have been made by the Directorate General of Islamic Institution, Ministry of Religious Affair in order to improve the quality of Islamic Educational Supervisor, because, these Supervisors plays an important role as a model for the school community, professionalism, discipline, and character. They are also having responsibility for carrying 
out their educational and assignment tasks.

A growing concern among educators is whether emerging school leaders are prepared to face these pressures and create schools that advocate for education that advances the rights and education for all children (Spring, 2001).

The school leader's role in developing a shared vision of learning; sustaining a school culture conducive to learning; ensuring appropriate management of school operations and resources; facilitating collaboration with families to respond to diverse needs; acting with integrity and fairness; and responding to the school's political, social, economic, legal, and cultural context (Cambron-McCabe, 2006, p. 112).

The Islamic Educational Supervisor, which is one of the most important parts of the National Education system, certainly must be familiar with the SNP (National Standard of Education). They have functioned as the main basis in the educational management system starting from the curriculum planning, implementation, and educational supervision to increase the quality of national education. They have functioned as an educational service provider to Islamic Educational teachers to improve the quality of learning and student learning outcomes and improving the quality of Islamic Educational teachers in terms of learning aspects. The Islamic Educational Supervisor also needs to have good quality in terms of School supervision to improve school quality management and student achievement.

We can say that a program can be considered successful if the curriculum 2013 PAI training program improves the quality of student learning outcomes and training programs have been running in accordingly with the program designed.

A good Islamic Educational Supervisor should involve intensively in advising the teachers regarding what the teachers have to do and not merely finding faults. The assistance provided by the Islamic Educational Supervisor to Islamic Educational teachers is not just an input or suggestion but must be based on the results of a research that has been done carefully to avoid miss of conduct and disoriented.

The 2013 curriculum training program for Islamic Educational Supervisors is intended to improve the quality of 2013 curriculum implementation, such as.

1. Improving the quality of Islamic Educational Supervisors as a partner of School Principal and Islamic Educational Teachers in implementing the 2013 Curriculum.

2. Improving the Islamic educational Supervisors as a teacher assistant in implementing the 2013 curriculum and improving the effectiveness of school planning supervisory tasks

3. Improving the Islamic educational Supervisors in helping our religious teachers to solve their learning problems and difficulties

4. To identify problems and try to find solutions to any existing problems dealing with the curriculum.

5. Improving the ability of Islamic Educational Supervisors in the field of 2013 curriculum

\section{Conceptuality of Islamic Educational Supervisor}

Quality teaching and instruction are the necessary conditions for successful learning in schools and institutions worldwide. Supervision in schools is accepted as a general leadership function intended to improve the performance of teachers' teaching and instruction. Glickman, Gordon, and Gordon (2004) have placed supervision as the backbone towards determining the effectiveness of the school.

The Directorate General of Islamic Education, Ministry of Religious Affair has carried out the 2013 curriculum implementation training program for Islamic Educational Supervisors and Islamic Educational Teachers in fulfilling their duties and responsibilities for the success of 2013 curriculum implementation Nationally and to create a new policy for the Implementation of 2013 curriculum comprehensively in order to support Government programs related to the Educational development program in term of Islamic Religious teaching and learning processes.

The main objectives of the 2013 curriculum development activities are generally in order to improve the student mindset, strengthen curriculum governance and deepening and expanding the material to strengthen the learning process in order to guarantee the compatibility between what is preferred and what is made and it is intended for improving the quality of the Islamic Religious Education Supervisor to do their jobs as Islamic Curriculum Supervisor and be able to implement 2013 Curriculum effectively and efficiently in accordance with their duties and be able to play a role in conducting good supervision so that the conducive learning is realized.

The 2013 Curriculum Implementation Training program for Islamic Religious Education Supervisors aims that participants can understand the policies made by the Directorate of Islamic Education, Ministry of Religious 
Affair regarding on how to improve the quality of Islamic religious education in schools and the characteristics of the 2013 PAI Curriculum (2013 Islamic Curriculum) in order to achieve the National program in disseminating the 2013 PAI Curriculum.

With the increasing the supervisory competencies in the field of 2013 curriculum, it is expected that the performance also will increase and has an impact on the quality of the educational process and be able to carry out the role and duties as a supervisor of Islamic Education.

The main idea is to have an Islamic education supervisor mastering the 2013 Islamic Curriculum higher than those possessed by Islamic Education teacher in terms of methodology, techniques who were under guided;

1. Having sufficient knowledge about various learning methodologies, techniques, creative, innovative and able to communicate, both oral and written and knowing the indicators of success and failure in teaching.

2. Having sufficient knowledge in terms of education quality management at the school level, especially regarding quality control programs/quality assurance.

3. Having the ability to influence, convinces, and motivates others, especially Islamic religious teacher and this includes the ability to develop international relations.

4. Having an adequate level of intellectual ability and be able to find the subject matter, analyze it and make decisions from the results of the analysis.

5. Having adequate knowledge in terms of systematic data collection and analysis of the data.

6. Having an adequate level of personal maturity, especially in the field of emotional maturity.

Competency in the field of academic supervision is important for Islamic Educational Supervisor (PAI supervisors) in carry out academic supervision in the field of Islamic Education to assess and nurture the Islamic religious teacher (PAI teachers) in order to improve the quality of Islamic Religious Teaching (PAI learning) and have a positive influence on the quality of learning and learning outcomes students.

Islamic Educational Supervisors must have an academic and managerial qualification and have ability and capability to supervise Islamic educational teacher in the field of 2013 Curriculum in order to develop and fostering teachers capability in field of Islamic curriculum, so that the quality of the learning process is increased and bring impacts to the quality of student learning outcomes.

The place of the Islamic Educational Supervisor in the educational system is very important because it has a vital role in the school management system and it is closely related to school planning and learning activities.

Several changes will bring a new challenge both internally and externally in the field of Islamic educational Systems; therefore the implementation of the 2013 Curriculum is a very strategic step in facing a global challenge in the future related to moral behavior and mindset changes. It has a management function needed for evaluating the performance of teachers to achieve goals and school programs by what has been planned. A good supervisor is a supervisor who can provide direction and guidance to the teachers he supervises.

The implementation of this training is one of the Government's priority programs at the Directorate General of Islamic Education such as:

1. The Implementation program aim to introduce a new 2013 curriculum to Islamic educational teachers and Islamic educational supervisors.

2. To create a new perspective regarding the learning process of Islamic teaching to Islamic Educational supervisors and creating a pleasant learning atmosphere.

3. Observing any difficulty deterring the implementation of the 2013 curriculum in targeting school.

The objectives of the 2013 curriculum implementation program such as:

1. Knowing the strategies values of 2013 Curriculum implementation.

2. Understanding the rationale curriculum and its elements.

3. Building the scientific approach concept by the necessities of the 2013 Curriculum and Character Education.

4. Recognizing Student Standard Competency (SKL), Core Competencies (KI), and Basic Competencies (KD).

5. Providing information regarding Islamic religious teaching and learning models.

The significance of the Implementation of the 2013 Curriculum is to determine, how many percentages of the 
training targets can be achieved and how the program is implemented and do we have room to correct the system and create new policies related to the Curriculum implementation based on the training result?

\section{Literature Review}

Evaluation is a term used in a scientific study that has developed into various scientific disciplines. The knowledge of this study or evaluation has provided any benefits and contributions in assessing the implementation of a program which in turn can provide recommendations to be made the basis for making an important decision in various programs.

Evaluation is an activity to look for something valuable about something; in looking for something, it also includes information that is useful in assessing the existence of a program, production, procedure, and alternative strategies proposed to achieve the objectives that have been determined. Worthen and Sander (1973, in Andersen 1971).

Evaluation is a systematic process of data collection, data analysis and interpretation of information to determine the level of achievement of teaching objective. Evaluation is the process of evaluation something based on criteria or goals that have been set, the decision is made on the object being evaluated (Djaali \& Mulyono, 2000).

Evaluation is perhaps the most complex and least-understood of the term. Inherent in the idea of evaluation is "value" when we evaluate, what we are doing is engaging in some process that is designed to provide information that will help us make a judgment about a given situation (Kizlik, 2014).

Good supervision involves activities that aid, direct and inform teachers of what should be done or have been done and not merely finding faults in the teacher's teaching. In the literature on instructional sciences, clinical supervision is a type of supervision that meets the stated requirements of good supervision (Sarfo \& Cudjoe, 2016).

Broadly speaking, it can be assumed that evaluation is a giving of values to the quality of a program and evaluation can be also be said as a process in carrying out planning, obtaining and providing the information needed to make alternative decisions.

\section{Method}

There are many designs and evaluation models used to evaluate the training programs and one of them is the CIPP Model which used to evaluate the implementation of 2013 Curriculum Training program theorized by Stufflebeam in 1983 which includes four elements, namely: C- Context, I-Input, P - Process and P-Products.

This model can be used effectively to evaluate the quality of educational and training programs. The context of this evaluation includes the objectives and the background of the implementation program.

Input context refers to the material, time, physical and human resources needed to carry out activities effectively. The process includes teaching and learning processes and products focusing on the quality of teaching and learning and its usefulness and potential benefits to society (Stufflebeam, 2003)

Stufflebeam's evaluation Model is based on four different kinds of evaluation information that are policymakers and administrators need to make their decision. These include context, input, process, and product evaluation information - here the acronym of CIPP.

Four aspects of the CIPP Evaluation Model (context, input, process, and output) help decision-makers to answer four basic questions regarding;

1. What to do (What should we do?); collect and analyze data to determine goals, priorities, and goals.

2. How do we implement it (How should we do it?); the condition of existing resources and the stages needed to achieve the goals and objectives or can also include the identification of programs in gathering information.

3. Is it done according to plan (Are we doing it as planned?); Step in making decisions about how well the program is implemented. By routinely monitoring ongoing programs and how well the program is implemented according to instructions and plans, whether there are conflicts that arise, staff support and morale, material strengths and weaknesses, and budget issues.

4. Is it successful (Did it work?); by a way of measuring the results and outcomes and comparing it with the expected program plan, to make the decision whether it is continued, modified, or stopped altogether.

The implementation of the 2013 Curriculum training program for Islamic Religious Education Supervisors was carried out because the curriculum is one of the important elements that can make a significant contribution to 
the quality of Islamic Studies and to develop our potential students to be someone who has quality in term of Curriculum competency.

The following indicators show if the training Implementation is successful:

1. After participating in the Curriculum Implementation Training participants are expected to be able to explain the rationale 2013 Curriculum of Islamic Education and Character and its relation to demands.

2. Participants are expected to be able to explain the elements of curriculum change, can analyze the relationship between the standard competency of graduates, core competencies, and basic competencies, as well as the stages and learning activities.

3. Participants are expected to be able to analyze teachers' books and student books.

4. Mastering the structure of the curriculum, and subject matter and the philosophy of teaching the material and being able to portray and associate the application of the science of religion that is taught with other sciences in everyday life.

5. Be able to analyze the suitability of the material with the academic potential possessed by students and as well the ability to prepare a learning Implementation Plan (RPP) based on the scientific approach.

6. Be able to carry out learning and teaching based on the scientific approaches (observing, questioning, exploring, associating and communicating).

\section{Research Finding}

Based on the results of the evaluation conducted in the process of implementing 2013 Curriculum Training, we can conclude that;

\subsection{Context Evaluation}

The purpose of a context evaluation is to define, identify and assess all the needs for the implementation of training program for Islamic Religious Education Supervisor by identifying problems and assessing whether all the objectives and needs of a training program are in line with the needs. Some questions related to the context are as follows:

a. Are the aims of this training program suitable or not?

b. Are the course materials taught relevant to the aims?

In terms of the aspect context of training, the training implementation program was designed to generate a solid coordination among policymakers, teachers and Islamic educational supervisors regarding the implementation training programs and the targeted audience.

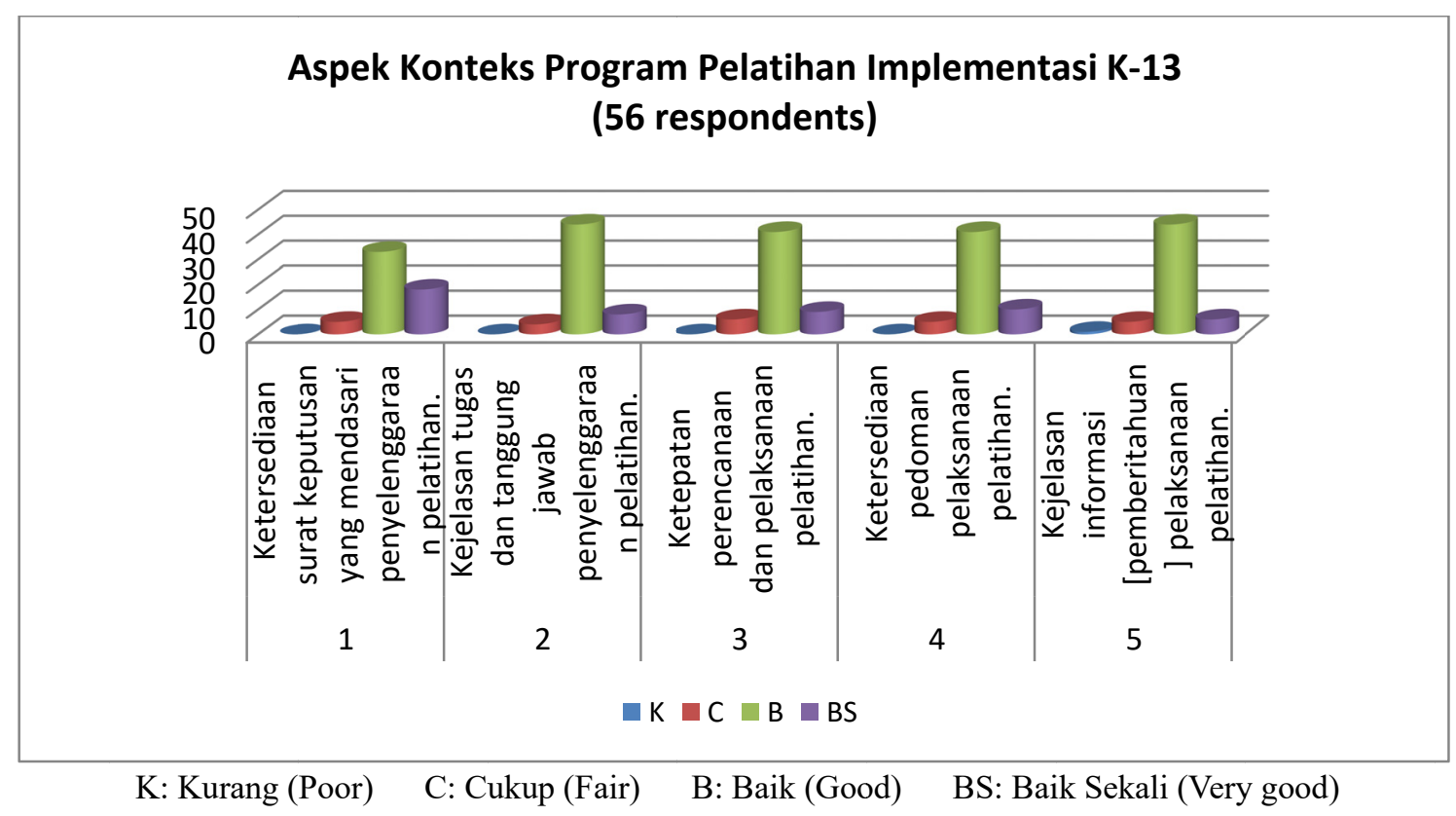


Based on the results of the data analysis above, it can be concluded as follows:

a. Regarding the availability of regulations that underlie the implementation of training; $91 \%$ of respondents said that the component material was recommended.

b. $89 \%$ respondent said that the accuracy of the planning and implementation of the training was above average.

c. The availability of implementation guidelines; $82 \%$ respondent said that they are good or very good.

From the research result, it can be concluded that the evaluation context regarding the Implementation training Curriculum 2013 for Islamic educational supervisor, in general, was reasonable, had fulfilled the requirements even though it was incomplete in some areas.

\subsection{Input Evaluation}

The purpose of input evaluation is to provide information regarding the resources used in the curriculum 2013 training implementation Program to meet the goals of the program. The input factors are the resources used in training such as human resources capital, infrastructure, curriculum material, and content.

Several questions that come under the context of input are:

1. What are the learning skills that can be obtained by the Islamic Educational Supervisor?

2. What type of resources should be used for effective training?

3. How are the instructors using their teaching skills for effective training?

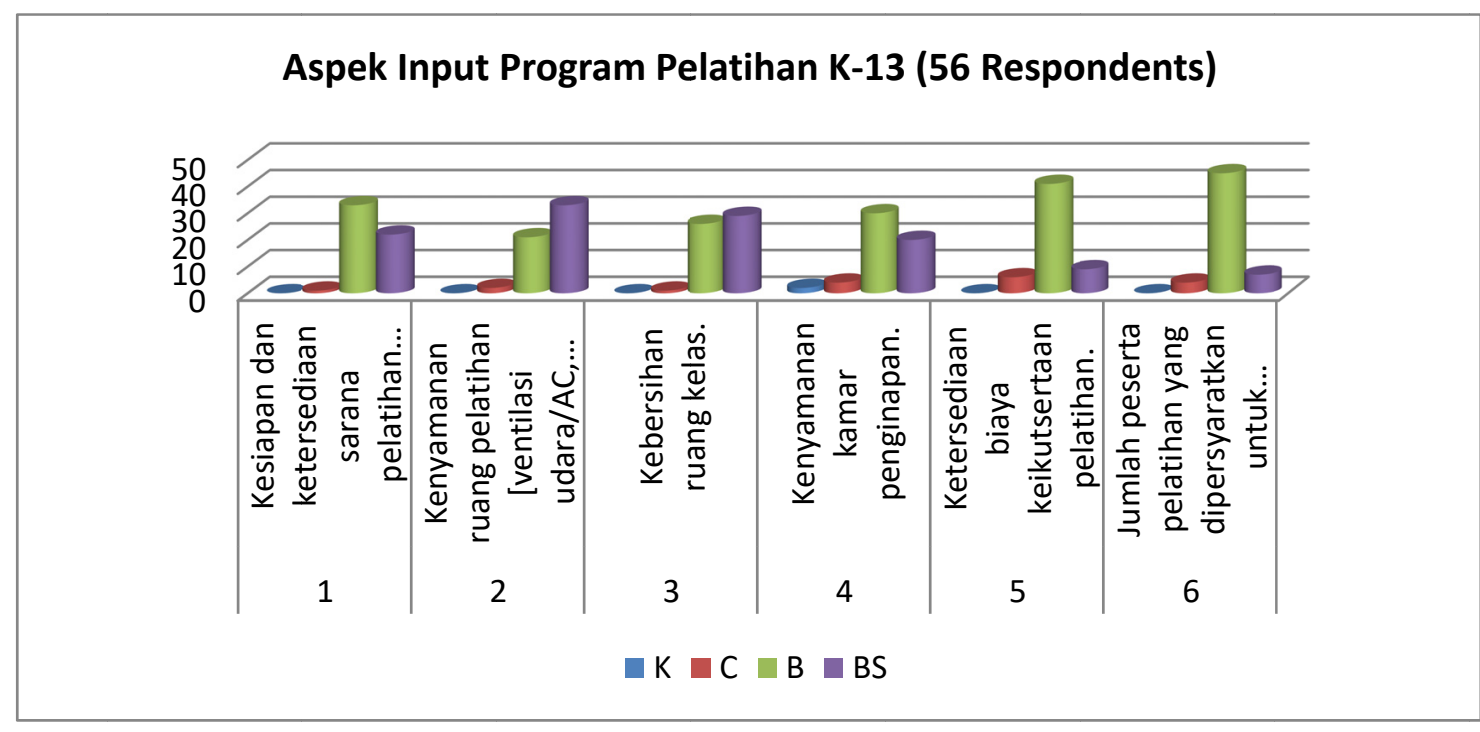
K: Kurang (Poor)
C: Cukup (Fair)
B: Baik (Good)
BS: Baik Sekali (Very good)

Related to the training material used in the implementation program, there are some area need to be improved, such as:

a. The training material, it needs to be more practical and simple material, not just concepts, theories, and lectures.

b. The quality of some lecturer/instructor is still inadequate and has not fully understood the material and the mechanism of a new 2013 curriculum implementation.

c. It is necessary to increase the budget to have more participants from the Islamic educational supervisor and increase the number of Islamic Educational Supervisors for training.

Based on the data analysis related input, it can be concluded as follows:

a. In general, $91 \%$ of respondents considered that the availability of training facilities was appropriate even though some issues needed to be addressed concerning some training materials that still needed further explanation and narration to be easily understood. 
b. The efficiency of training; $90 \%$ of participants said it was good. In other words, the targets or peoples under training are following the needs and have fulfilled the criteria as trainees.

c. Concerning participation costs; $83 \%$ of respondents said it was above average (good- very good). In general, all budgets needed for the training implementation program supplied by the Government / Ministry of Religious affairs, especially the Directorate General of Islamic Education.

In term of training input, most of the participants said had fulfilled the needed for a successful training program.

\subsection{Process Evaluation}

The focus of the process evaluation is to identify how the implementation program works and how the input is used effectively to achieve the desired goals, objectives, targets.

The training process includes a systematic approach, teaching activities, training process related to the following questions.

a. How the training was carried out

b. Is the process of the training effective?

Implementation of training has to be in line with the rules, the needs and the targets of the training program. In the case of the training participants, most of them are not talented and less awareness regarding the content of training material due to a huge amount of training material but taught in a short period of time (only 3 days of training).

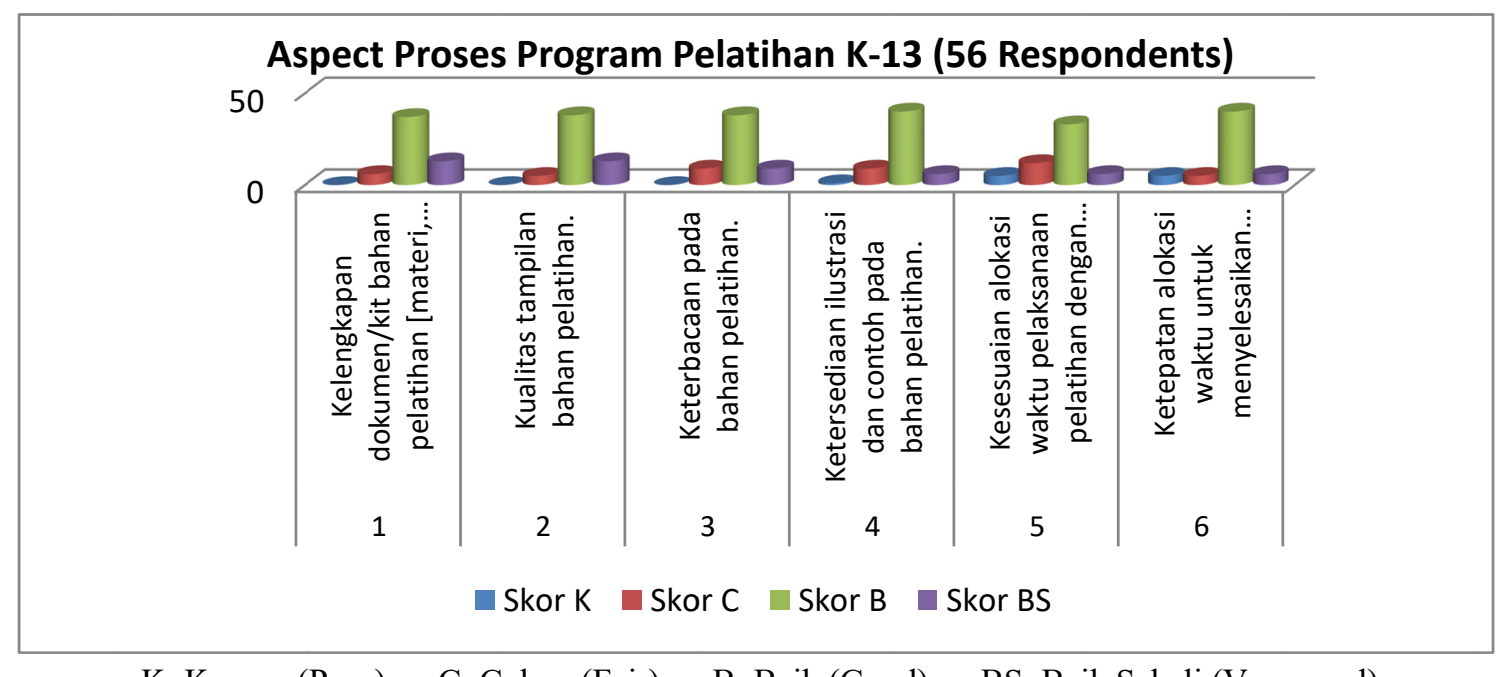

K: Kurang (Poor) $\quad$ C: Cukup (Fair) $\quad$ B: Baik (Good) $\quad$ BS: Baik Sekali (Very good)

The evaluation process component aims to describe how the projected resources are used to support the implementation of the 2013 curriculum implementation training program and the results obtained as follows

a. The comprehensiveness of documents training materials; $89 \%$ of respondents said that they were suitable. A small number of participants did not understand the content of training materials even though the instructor or trainer had explained in detail to the point where they were repeated several times for specific training material.

b. The quality of training materials; $91 \%$ of respondents said that it was recommended, very well designed with the addition of the learning videos, so that participants could easily understand the material in training.

c. The readable of training materials; $83 \%$ of participants agreed.

d. Time allocations; only $69 \%$ of participants stated that the quality of instructors in terms of time management was average.

\subsection{Product Evaluation}

The product evaluation of the 2013 Curriculum Implementation program includes the Islamic Educational Supervisors' proficiency related to their skills, knowledge, and competency that used in conducting supervisory tasks. 
The purpose of the implementation of a 2013 curriculum training program for Islamic Educational Supervisors is to improve the quality, productivity, and competency and be able to perform their tasks well.

Based on field monitoring, we found that:

a. There is no even distribution regarding the implementation of the 2013 curriculum training across the nation.

b. The quality of Islamic Educational Supervisors, which is mastering the curriculum 2013 inadequate and not optimal.

c. The quality of Islamic Educational supervisors, although from year to year has been increased, both in terms of educational qualifications, supervision competencies and managerial competencies along with the trend of educational development in Indonesia, but from the results of the study, we found that the ability and Islamic Educational Supervisors rate in accepting educational system changes and a new concepts of education including for the curriculum changes acceptance as well as their participation in various competency improvement training program is lesser compare to their counterpart, the Islamic Religious teachers and that is unjustifiable because teachers are more competent than their supervisor.

d. A numbers of Islamic Educational Supervisors do not have full awareness and responsibility in carrying out their duties.

e. A few of them do not have adequate facilities to carry out duties as Islamic Educational supervisors.

\section{Conclusion and Recommendation}

By implementation of a new 2013 curriculum, we do expect to answer various challenges and problems that are faced by our student, now and in the future and we can improve the quality of an educational institution, empowering educational resources and improving the quality of education by national expectations throughout the educational process.

If several problems as mention above cannot be solved, the process of school supervision activities will not succeed and that means changing the educational system in school will not run well.

Islamic Educational supervisors are the most important element of the educational system but on the other hand, the quality of our Islamic Educational supervisors is not good enough to deal with a new curriculum.

The above mention problems bring impact on school program management, several Islamic Educational Supervisors have little attention on the program and to solve those mention problems above, various steps must be taken such as:

1. Islamic educational supervisors should be given more training, guidance and workshops with richest and more complex material/Syllabus compare to the Islamic Educational Teachers; otherwise their function as supervisors for Islamic Educational Teachers will not work properly and we should train them both differently because their function in term of the academic management program is not the same

2. The Directorate General of Islamic Education needs to complete regulations regarding the duties and authority of Islamic Educational Supervisors to have their maximum function and having their position in the right place, so their existence is protected by legitimate and formal regulations and also respected.

3. Improving the quality of Islamic Educational Supervisors which includes enhancing competence in Educational Management and religious values. Competency Enhancement Programs as Islamic Educational supervisors must be carefully planned and sustainable based on research.

4. Tighter selection of Personnel for Islamic Educational Supervisor by carrying out a full analysis of their abilities (self-competency).

5. Recruitment of Islamic Educational Supervisors in the future must be reorganized and they must be selected from the best Islamic Educational teachers and other candidates from different backgrounds are not accepted. This is tough, but we have to fix it and make them a respected Islamic educational supervisor.

\section{References}

Arikunto, S., \& Cepi Safruddin, A. J. (2008). Evaluasi Program Pendidikan, PanduanTeoritis Praktis bagi Praktisi Pendidikan. Jakarta: Bumi Aksara.

Arikunto, S., \& Jabar, C. S. A. (2008). Evaluasi Program Pendidikan. Pedoman Teoritis Praktis Bagi Mahasiswa dan Praktisi Pendidikan, Bumi Aksara.

Azhari, A. (2004). Supervisi Rencana Program Pembelajaran. Rian Putra, Ciputat. 
Bridges, D. (2003). Education, autonomy, and democratic citizenship: Philosophy in a changing world. England. https://doi.org/10.4324/9780203442777

Bush, T., \& Coleman, M. (2008). Manajemen Strategis Kepemimpinan Pendidikan. IRCiSoD Jogjakarta.

Coulter, D., \& Wiens, J. R. (1999). What is educational about educational leadership? Education Canada, 39(2). Toronto, Canada.

Fullan, M. (1998). Leadership for the 21st Century: Breaking the Bonds of Dependency. Electronic journal, $55(7)$.

Guskey, T. R. (2000). Evaluating Professional Development. Corwin Press, Inc, A. Sage Publication Company Thousand Oak, California.

Hasan, Y. A. (2002). Pedoman Pengawasan Untuk Madrasah dan Sekolah Umum. Jakarta. CV. Mekar Jaya.

Jean-Marie, G., Normore, A. H., \& Brooks, J. S. (2009). Leadership for Social Justice: Preparing 21st Century School Leaders for a New Social Order. Journal of Research on Leadership Education, 4(1). https://doi.org/10.1177/194277510900400102

Kizlik, B. (2014). Measurement, Assessment, and Evaluation in Education. Robert Kizlik and Associated, Boca.Raton, Florida.

KwakuSarfo, F., \& Cudjoe, B. (2016). Supervisors' Knowledge and Use of Clinical Supervision to Promote Teacher Performance in basic schools. International Journal of Education and Research, 4(1).

Mangkunegara, A. P. (2005). Evaluasi Kinerja. Bandung: Refika Aditama.

Nata, A. (2008). Manajemen Pendidikan, Mengatasi Kelemahan Pendidikan Islam di Indonesia. Jakarta: Prenada Media Group.

Rivai, V. (2005). Manajemen Sumber Daya Manusia. Raja Grafindo Persada. Jakarta.

Rohiat. (2008). Manajemen Sekolah. PT. Refika Aditama, Bandung.

Sallis, E. (2002). Total Quality in Management. Kogan Page Ltd, London.

Sallis, E. (2010). Total Quality Management in Education, Manajemen Mutu Pendidikan. Kogan Pagen Ltd, 120 Pentonville Road, London N19JN UK.

Umiarso, \& Zamroni. (2011). Pendidikan Pembebasan dalam Perspektif Barat \& Timur. Jakarta.

Usman, H. (2008). Manajemen: Teori, Praktik dan Riset Pendidikan. Bumi Aksara, Jakarta.

Wibowo. (2014). Manajemen Kinerja. Jakarta. Raja Grapindo Persada.

Yukl, G. (2012). Leadership in Organizations. USA.

\section{Copyrights}

Copyright for this article is retained by the author(s), with first publication rights granted to the journal.

This is an open-access article distributed under the terms and conditions of the Creative Commons Attribution license (http://creativecommons.org/licenses/by/4.0/). 